\title{
Evaluation of Single-use Reprocessed Laparoscopic Instrument Sterilization ${ }^{1}$
}

\author{
Cristiane de Lion Botero Couto Lopes ${ }^{2}$ \\ Kazuko Uchikawa Graziano ${ }^{3}$ \\ Terezinha de Jesus Andreoli Pinto ${ }^{4}$
}

This experimental, comparative, laboratory study evaluated the effectiveness of the sterilization of single-use laparoscopic instruments - SULIs (grasper, dissector, scissors, Veress needle and electrosurgical probe system), after contamination-challenge with bacterial spores and sheep blood, and compared the results of the sterilization tests with those of the equivalent reusable instruments. The cleaning methods used were; ultrasonic washer with pulsatile water jet and enzymatic detergent, manual cleaning, cleaning with pressurized water and rinsing. The SULIs were sterilized with ethylene oxide and the reusable instruments in an autoclave. Sterility tests showed $100 \%$ negative results for recovery of contaminate microorganisms in both groups. It was concluded that, regarding the sterilization, that it is possible to reprocess SULIs.

Descriptors: Sterilization; Cross Infection; Laparoscopy; Video-Assisted Surgery; Equipment Reuse.

\footnotetext{
1 Paper extracted from Master's Thesis "Avaliação da esterilidade dos instrumentais laparoscópicos de uso único processados após contaminação artificial", presented to Programa de Pós-Graduação em Enfermagem, Escola de Enfermagem, Universidade de São Paulo, SP, Brazil. This research was supported by Fundação de Amparo à Pesquisa do Estado de São Paulo (FAPESP), process \# 2006/51113-6.

${ }^{2}$ RN, M.Sc. in Nursing, Hospital Universitário, Universidade de São Paulo, SP, Brazil. E-mail: crisdelion@hu.usp.br.

${ }^{3}$ RN, Ph.D. in Nursing, Full Professor, Escola de Enfermagem, Universidade de São Paulo, SP, Brazil. E-mail: kugrazia@usp.br.

${ }^{4}$ Pharmaceutical, Ph.D. in Drug and Medication, Full Professor, Faculdade de Ciências Farmacêuticas da Universidade de São Paulo, SP, Brasil. E-mail: tjapinto@usp.br.
}

Corresponding Author:

Cristiane de Lion Botero Couto Lopes

Rua Artur Pinto da Rocha, 107

Bairro: Jaguaré

CEP: 05335-060 São Paulo, SP, Brasil

E-mail: crisdelion@hu.usp.br 


\section{Avaliação da esterilidade do instrumental laparoscópico de uso único reprocessado}

O presente estudo, experimental, laboratorial e comparativo, teve como objetivo avaliar a eficácia da esterilidade dos instrumentos laparoscópicos de uso único (ILUU): grasper, dissector, tesoura, agulha de Veress e sistema de sonda de eletrocirurgia, após contaminação desafio com esporos bacterianos e sangue de carneiro, e comparar os resultados dos testes de esterilidade com aqueles dos instrumentos equivalentes "permanentes". Para limpeza, utilizou-se lavadora ultrassônica com jato pulsátil e detergente enzimático, limpeza manual, água sob pressão e enxágue. Os ILUUs foram esterilizados por óxido de etileno, os instrumentos "permanentes" em autoclave. Os testes de esterilidade acusaram resultados $100 \%$ negativos para a recuperação dos micro-organismos contaminantes, nos dois grupos. Concluiu-se que, em relação ao alcance da esterilidade, é possível reprocessar ILUU.

Descritores: Esterilização; Infecção Hospitalar; Laparoscopia; Cirurgia Vídeo-Assistida; Reutilização de Equipamento.

\section{Evaluación de la esterilidad del instrumental laparoscópico descartable reprocesado}

Se trata de un estudio, experimental, de laboratorio y comparativo, que evaluó la eficacia de la esterilidad de los instrumentos laparoscópicos de uso único(ILUU): grasper, disector, tijera, aguja de Veres y el sistema de sonda electroquirúrgica, después de "contaminación desafío" con esporas bacterianas y sangre de carnero; los resultados de las pruebas de esterilidad fueron comparados con los de los instrumentos equivalentes "permanentes". Para efectuar la limpieza se utilizó: lavadora ultrasónica con chorro pulsante y detergente enzimático, limpieza manual, agua bajo presión y enjuague. Los ILUU fueron esterilizados con óxido de etileno, los instrumentos "permanentes" en autoclave. Las pruebas de esterilidad mostraron resultados $100 \%$ negativos para la recuperación de los microorganismos contaminantes en los dos grupos. Se concluye que, en relación al alcance de la esterilidad, es posible reprocesar los ILUU.

Descriptores: Esterilización; Infección Hospitalaria; Laparoscopía; Cirugía Asistida por Video; Equipo Reutilizado.

\section{Introduction}

Single-use devices (SUD) have been used for more than half a century in healthcare. Initially, they were manufactured with the aim of solving problems faced by health professionals, resulting from overload of work in Materials and Sterilization Centers (MSC), as well as the advantage of ensuring the availability and quality of the material, due to it always being of first use. However, some of these devices have a very high cost to be discarded after one use, due to the advanced technology incorporated into their manufacture: electronic circuits, membrane technology, optical components and highcost miniaturized components. As a strategy to circumvent the problem, the health facilities began to reuse them ${ }^{(1)}$.

Single-use devices are generally produced from thermo-sensitive and less noble raw materials, such as plastics and elastomers. Most of these cannot be dismantled and have internal spaces with difficult access for cleaning. This situation generates doubts about the permanence of residual organic matter in the material and the safety of the sterilization process.

In Brazil, current legislation prohibits the reuse of single-use instruments used for laparoscopic surgery. However, this prohibition was not based on scientific 
evidence, but on conflicts of interests, that resulted from public consultations (No. 98 on 06/12/2001 and No. 17 on 19/03/2004) and also a public hearing on 03/06/2005. Thus, single-use laparoscopic instruments (SULIs) were included in the list of materials prohibited to be reused, although other SUDs, no less complex, such as myocardial stabilizers, angioplasty catheters, vitrectomy probes, to name a few, were not included (2).

Considering that the reuse of SULIs occurred with relative intensity in various regions of Brazil before its prohibition, the realization of this research is justified, as a way to evaluate the risk of hospital cross-infection of patients who undergo procedures with reused SULIs (grasper, dissector, scissors, Veress needle and electrosurgical probe system). It is also believed that this study will help to elucidate the safety aspects of the reprocessing of devices of complex conformation.

In reviewing the literature only one study ${ }^{(3)}$ was found that aimed to evaluate the achievement of sterilization of laparoscopic scissors - one of the devices studied in this investigation. In that study, the sterilization of laparoscopic scissors was not achieved. However, this result is inconsistent with that achieved throughout the years of utilization of reused SULIs. It is understood, therefore, that there is a need for more research on this topic. Based on this reasoning, it was concluded that the issue remains controversial.

Starting from the premise that the proper and careful cleaning of the devices is the main determinant of the result of effective sterilization(4-5), especially when the low temperature method is employed, the initial hypothesis of this study was that, even facing the contamination-challenge of samples with 1 million sporulated bacteria, added to blood, sterilization may be achieved when the appropriate technology for the process is applied, especially regarding cleaning.

\section{Aims}

To evaluate the efficacy of the sterilization of singleuse laparoscopic instruments used in video-surgicallaparoscopy after the contamination-challenge.

To compare the results of the sterility tests with those of similar reusable instruments.

\section{Materials and Method}

This was an experimental, comparative, laboratory study, in which all variables could be controlled. The research steps were performed in the following laboratories: Microbiological Testing Laboratory of the
Department of Medical-Surgical Nursing, School of Nursing, University of São Paulo (USP), the laboratory of the Control of Medicines, Cosmetics, Household Cleaning Products, related products and their raw materials (CONFAR) of the Pharmacy Department, Faculty of Pharmaceutical Sciences of USP, and the Materials and Sterilization Central of the University Hospital of USP. For this study 120 devices marketed as single-use were used in the experimental group: 25 for validation tests of the method and 95 for the data collection itself. A total of 35 "reusable" instruments were employed as the comparison group throughout the different phases of the research. The sample size in the experimental group had a power of $99.9 \%$.

The SUDs used in this study were purchased from the company Ethicon ${ }^{\circledR}$ Endo-Surgery, Inc. , the packaging of which contained the following identification: Grasper forceps: 1 ENDOPATH - $5 \mathrm{~mm}$ Grasper with Ratchet Handle - lot V42R89, 2009-08, ref 5DCG; Scissors: 1 ENDOPATH - $5 \mathrm{~mm}$ Curved Scissors with Monopolar Cautery - lot R4RC42, 2007-01, ref 5 DCS; Dissector forceps: 1 ENDOPATH - $5 \mathrm{~mm}$ Curved Dissector with Monopolar Cautery - lot V42E5K, 2009-07, ref 5DCD; aspirator/irrigator: 1 ENDOPATH - Electrosurgery Probe Plus II - lot V41H8K, 2009-05, ref EPH01- Pistol Foot Control; stem/electrocautery: 1 ENDOPATH Electrosurgery Probe Plus II - lot R4TH60, 2007-06, ref EPS03 - 5 mm Right; Veress needle: 1 ENDOPATH - Ultra Veress Insuflation Needle with Luer Lock Connector - lot X43W1L, 2009-11, ref UV 120 - 120 mm Ultra Veress.

The SUDs were intentionally contaminated with a suspension of approximately $10^{6} \mathrm{CFU}$ (colony forming units)/ml of spores of Bacillus atrophaeus var. niger (American Type Culture Collection - ATCC 9372) quantified, standardized and diluted in sterile defibrinated sheep blood. The contaminant inoculum was injected into the existing internal spaces of the devices. Following this the instruments were left for 80 minutes on a lined surface and covered with impermeable sterile drapes, maintaining contact with the contaminant inoculum. The choice of this micro-organism was justified by the fact that this is the standard biological indicator for monitoring sterilization cycles by means of ethylene oxide (EtO), the method was chosen for the experiments due to its high diffusibility and compatibility with the thermo-sensitive materials ${ }^{(6)}$.

The reusable instruments underwent the same process of contamination, except with Geobacillus stearothermophilus - ATCC 7953, due to this being the standard microorganism in the biological indicators to 
monitor the steam autoclave sterilization cycles, the type of sterilization recommended for stainless steel devices ${ }^{(7)}$.

Next, the dried, contaminated instruments were immersed in drinking tap water for approximately 30 minutes in order to moisten them. In sequence, all devices were subjected to enzymatic detergent cleaning, first in an ultrasonic cleaner with pulsatile water jet; after washing this was complemented with manual cleaning, as required by the test-protocol described below, prepared for reprocessing, both for the singleuse and reusable devices.

The test-protocol steps were: dismantling of the reusable laparoscopic forceps; wetting of the material by immersion in tap water for 30 minutes, immersion of the parts in a solution of enzymatic detergent* as directed by the manufacturer, washing of the instruments in an ultrasonic washer with pulsatile water jet specific for the cleaning of cannulas and instruments (manufactured by H. Stratnner $\left.{ }^{\circledR}\right)$; additional manual cleaning of each piece with $2 \mathrm{~mm}$ diameter brushes (internal washing of the cannula of the Veress needle, stem and handle of the Electrosurgical Probe System), and delicate brushes for washing the serrations of the active part of the forceps; rack and pinion, handles and other niches and recesses of all the pieces; rinsing of the material with the aid of a high pressure water gun, directed into the internal structure of the instrument; final rinse with sterile distilled water; support of the devices in baskets lined with white drapes for a few minutes to facilitate drying and inspection for blood residue; dried with compressed air and soft medical compresses; rigorous inspection for cleanliness and integrity of devices with the aid of an image intensifier lens with focusing light; reassembly of the "reusable" forceps; individual packaging of the devices in a double-pack of surgical grade paper, placing inside the package a multi-parameter chemical integrator (class 5); sterilization of SUDs by ethylene oxide gas, and autoclave with saturated steam under pressure with pre-vacuum for the reusable instruments; forwarding of sterile samples for the sterility test.
It should be noted that, prior to the experiments, all the microbiological analytical methodology was validated by the technical team of the CONFAR laboratory of the Faculty of Pharmaceutical Sciences of USP, using the following phases: (PHASE 1) samples of each of the device types, both single-use and reusable, were subjected to the counting of CFU per unit of material (CFU/material) after microbial contamination, after the cleaning procedure and before sterilization (PHASE 2). In both steps the recovery of contaminants was confirmed, which attested to the adherence of the inoculum to the instrument, and the consequent challenge to the sterilization phase, giving continuity to the experiments. Such validation of the method constituted a positive control and aimed to ensure the presence of the test micro-organisms in the devices in order to challenge the sterilization.

The sterility tests consisted of experiments to verify the recovery of the test micro-organisms in standard culture medium, in which they had previously proliferated. The contaminated devices, after cleaning and sterilization, were cultivated directly in soybeancasein culture medium, considered suitable for the recovery of a possible test micro-organism surviving the methods of reprocessing. The incubation period was 14 days, with daily readings of turbidity of the culture medium, with Bacillus atrophaeus incubated at $37^{\circ} \mathrm{C}$ and Geobacillus stearothermophilus at $56^{\circ} \mathrm{C}$.

With the SUDs, the tests were destructive. Under laminar flow, each material was broken using sterile pliers so that the samples could be completely immersed in the culture medium. The instruments of the comparison group were dismantled and also immersed directly in the culture medium.

\section{Results}

The results of the microbiological cultures of the video-surgical-laparoscopic devices marketed as singleuse and the reusable devices, after the contaminationchallenge, cleaning and sterilization are presented in Table 1.

Table 1 - Microbiological results of the sterility testing of the SUDs and reusable devices after the contaminationchallenge, cleaning and sterilization.

\begin{tabular}{cc}
\hline \multicolumn{1}{c}{ Contaminant micro-organism } & Results \\
\hline Presence of microbial growth of Bacillus stearothermophilus - ATCC 7953 & zero/35 $^{\dagger}$ \\
Presence of microbial growth of Bacillus atrophaeus - ATCC 9372 & zero/95 \\
\hline
\end{tabular}

${ }^{+}$The total number of reusable material samples was lower than the number of single-use material samples, due to the number of parts after dismantling. Each piece of the dismantled material was considered a sample unit.

* Basic composition of the enzymatic detergent used in the experiments: amylase, protease, lipase and carbohydrase enzymes, nonionic surfactants and isopropyl alcohol 
According to Table 1, no bacterial growth of Bacillus atrophaeus - ATCC 9372 or Geobacillus stearothermophilus - ATCC 7953 was recovered in the respective samples of the experimental group nor in the comparative one.

\section{Discussion}

This study provides scientific evidence of the technical possibility to sterilize devices marketed as single-use for video-surgical-laparoscopy, produced from plastics and elastomers, which cannot be dismantled and are of a complex conformation, which are: grasper, dissector, scissors, Veress needle and electrosurgical probe system.

Studies with similar objectives to those of this research - verifying the safety of reprocessing SUDs regarding the sterility implications - were developed by some authors ${ }^{(2,8-10)}$ and yielded different results: In 2002, researchers $^{(3)}$ carried out sterility tests of laparoscopic scissors and scalpels previously contaminated with spores of Bacillus atrophaeus - ATCC 9372, subjected to cleaning and then EtO sterilization and did not achieve success. These results contradict the result of this research, which showed the elimination of all of the same sporulated micro-organisms, after cleaning and sterilization in EtO. The analysis of the methodological procedures employed by the authors of the study allowed the sterilization failure to be assigned to the fact that the devices had not been cleaned using the appropriate technological resources, since the researchers chose to wash them in a thermal washer/disinfector (pressurized water jets), this equipment is suitable for washing devices of a simple conformation, because its power of removal of dirt is less than the cleaning methods employed in this research. The cavitation action of the ultrasonic washer for cleaning devices with narrow lumen and complex conformations, associated with pulsatile water jet washing is, theoretically, a resource of greater cleaning power. There is not, in the cited work, reference to the manual cleaning that, with this category of devices, should complement or precede automated cleaning. Thus, it can be inferred that the fact of not having achieved sterilization is attributed to cleaning inefficiency, corroborating the premise that the cleaning is the core of reprocessing. Another factor that may have led to the opposite outcome in the study reviewed was that the devices had been exposed to half the time of EtO sterilization practiced in the care context and recommended in the literature. This decision to impute a greater challenge to the experiments was based on the ISO 14937 standard, which indicates an additional challenge for validation testing of sterilization.

The reusable instruments for video-surgicallaparoscopy are extremely difficult to clean, since they present recesses and spaces that allow the accumulation of organic matter. In the present study, even with careful practices for dirt removal, one pair of reusable Stors ${ }^{\circledR}$ forceps and two reusable Edlo ${ }^{\circledR}$ vacuum/irrigators remained with residues of blood, discovered at the time of drying of the devices with pressurized air and during the visual inspection.

It was noted that the reusable Veress needles were as vulnerable to the retention of organic matter as the single use ones. It was observed that the reusable needle could be dismantled into 04 parts, enabling better access for cleaning the cannula, however, the metal used in the manufacture of the cannula prevents viewing of the internal part of the lumen to check the cleaning. In the equivalent single-use needle, there is no possibility of dismantling the cannula, but this is totally transparent and allows a full view of any residual organic matter after internal cleansing by sonication. The longest part of the needle itself, which penetrates the tissues of the patient, is identical in both types; neither of which allow the viewing of the internal space or access of appliances for the cleaning of the lumen, the cleaning only being possible with an ultrasonic washer with pulsatile water jet.

The same similarity between the single use and the reusable devices is found in the single-use pen handle scalpel and its reusable equivalent. The comparison between the two models in relation to the success of cleaning and sterilization was also the object of research. The results showed no significant difference in the degree of sterilization between them ${ }^{(11)}$. A paradox regarding the Veress needles is that the single-use needle couples with great firmness to the terminal of the ultrasonic washer with pulsatile water jet, which does not happen with the reusable ones. Accordingly, the flow pressure in the lumen of the needle is less, due to the "leakage" of water flow through the lateral orifices due to disassembly of the device itself.

The analysis of the negative results of the microorganism CFU count for the material in the experimental group and for the reusable comparative group, after the contamination-challenge with similar outcomes, demonstrates the need to review the concept of "single use" devices of high cost, since there is evidence that it was possible to sterilize the devices even with the 
contamination-challenge, which is unlikely to be a real scenario in care practice. In the case of the pens handle scalpels, the best performance regarding efficacy of sterilization was achieved when the automated cleaning technique was applied(11).

A study ${ }^{(10)}$ performed with single-use reprocessed trocars after the first use in patients undergoing elective laparoscopic cholecystectomy, found results of achieving sterility in $100 \%$ of the sample, after cleaning and sterilization with three different methods at low temperatures (ethylene oxide, low temperature steam and formaldehyde, and hydrogen peroxide plasma). The low impact of the results of this study was due to sporulated micro-organisms not having been used together with organic matter, which constitutes a real challenge for reprocessing. In the study in question, only $46.5 \%$ of the sample devices showed the presence of micro-organisms before cleaning, which represents a low challenge considering the aim of the research.

In 2009, a study(12) that evaluated the microbial load on instruments used in clean orthopedic surgery, found a maximum of $10^{2} \mathrm{CFU}$ of the genus Bacillus, per instrument, this micro-organism is able to sporulate under adverse environmental conditions. In the present study, the sporulated microbial challenge was approximately $10^{6} \mathrm{CFU} /$ instrument.

The granting of the stamp 'single-use' is strongly supported by the fact that the single-use material is complex and not able to be dismantled for cleaning, along with their non-noble raw materials (plastics and elastomers) that cannot resist aggressive and repetitive methods of cleaning and sterilization. Comparing the reusable video-surgical-laparoscopic forceps with the single-use ones, it was noted that, in these, there are virtually no empty internal spaces in the structure, and they could even be considered a 'solid material', which may explain the success in achieving their cleaning and sterilization in this study. It is noteworthy that the results of the present study were obtained after contaminationchallenge $\left(10^{6} \mathrm{CFU} / \mathrm{ml}\right.$ of sporulated microorganisms diluted in blood) which supports the findings of the technical possibility of sterilizing SUDs. The great contribution made by this research is the clarification that the reuse of single-use devices may be possible if there is quality in the work process for their processing.

Other studies have been published with outcomes similar to this study regarding the elimination of microorganisms inoculated as a challenge. In 2003, a study ${ }^{(8)}$ compared manual and automated cleaning for the reprocessing of single-use triple lumen papillotomes. Its use was simulated with the contamination of material with ATS (Artificial Soil Test - patent No: 6.447.990, 24/02/2001, www.uspto.gov composed of basic medium, sterilizedsheepblood (10\%v/v) endotoxin >2,000,000UE/ $\mathrm{ml}$ derived from E. coli 0127:B8, Protein: $85.2 \mathrm{mg} / \mathrm{ml}$, Carbohydrate: $12.3 \mathrm{mg} / \mathrm{ml}$ and Hemoglobin: $4.12 \mathrm{mg} /$ $\mathrm{ml}$ together with Enterococcus faecalis and Bacillus stearothermophilus). Direct and indirect tests were performed to detect residues of proteins, carbohydrates, and hemoglobin in order to evaluate the efficacy of the cleaning and presence of endotoxins, achieving superior results for the devices submitted to the automated cleaning by ultrasonic washer with backflow when compared to manual cleaning. In the study for evaluation of sterilization through EtO, the results have shown the total elimination of test micro-organisms.

Another study ${ }^{(9)}$ evaluated the efficacy of the cleaning and sterilization of cardiovascular angiographic catheters after clinical use and artificially contaminated. The single-use catheters were subjected to intentional contamination with Artificial Test Soil (ATS) plus Enterococcus faecalis and Pseudomonas aeruginosa. The results of microbiological testing, after 100\% EtO sterilization of the catheters, were negative for all sample units. Concerning the results of tests for the presence of endotoxins, the study showed that the most indicated method was to flush the catheters with sterilized water treated by reverse osmosis after cleaning, due to it achieving total absence of endotoxins in the devices tested. The efficacy of the cleaning was assessed by direct and indirect biochemical tests on the catheters, after the first clinical use and in situations of simulation with ATS for up to 5 reuses. Regarding the results of the cleaning tests, none of the methods were effective in the complete removal of organic residue intentionally added to the catheters. These results may be indicative of the presence of biofilms on these devices. In the conclusion of the study, the author reinforces the need to establish maximum acceptable parameters of organic residues and to carry out clinical observational studies which permit the determination of the clinical significance of the presence of such residues (carbohydrate, protein and hemoglobin) and of endotoxins.

A relevant concern, regarding the reprocessing of devices, is the biofilms that may be present mainly in areas of difficult access for cleaning. Biofilms are "structured communities of cells of microorganisms, embedded in a polymeric matrix and adherent - exopolysaccharides - to an inert or living surface"(13). It is known that when it is not possible to completely dismantle a material for 
total cleaning it is more susceptible to the presence of biofilms and that bacteria and fungi can protect themselves from external factors and multiply in the biofilms representing a potential risk of cross infection. Biofilm formation is theoretically feasible on material with surfaces which cannot be completely scrubbed in each cleaning process, as in the present investigation. This reinforces the categorization of these devices as 'limited use'. Considering that the financial factor is the main determinant for the reuse of expensive SUDs, the number of reuses should be proportional directed by the unit costs of these. One study(14) found that 10 reuses of video-surgical-laparoscopic accessories, for the study site, was compatible with the high unit costs of these.

There is consensus that the efficacy of the sterilization should be explored through the destruction of bacterial spores, such as the biological indicators that monitor the sterilization cycles in the routine of a MSC. However, as future research, it is worth exploring the issue "microbiological safety in the reuse of SUDs" through the contamination-challenge with biofilm forming microorganisms such as $P$. aeruginosa, considering that SUDs cannot be dismantled, as a rule, to be cleaned, which, in theory, favors the formation of biofilms.

One of the alerts in the discussion of reuse of single-use devices is the evaluation of the functionality of the material before exploring the possibility of achievement of sterility. A study, conducted in Germany in 2008, demonstrated reliability in the single-use laparoscopic ultrasonic scalpel reprocessed once, when compared to the new ${ }^{(15)}$. Thus, in our context, it can be affirmed that the validation of the reuse of the video-surgical-laparoscopic accessories as to their functionality has been empirically approved by the surgeons, direct users of these devices. Prior to the explicit prohibition by legislation of the National Health Surveillance Agency (ANVISA)(2), the practice of reuse of the devices investigated in this study was frequent within the national reality, and many surgeons claimed to prefer the reprocessed single-use material rather than the reusable ones, which contributes to reinforce the practice of reuse. Thus, it is possible to affirm that care practice has already tested and approved the functionality of these reprocessed single-use devices, illegally and without scientific justification.

This study was limited to the investigation of the achievement of sterility. However, other potential hazards may be present in the material, even when sterilized: the presence of biofilms, endotoxins, and residues of blood proteins and of toxic products used in the reprocessing, among others. These risks deserve further studies to effectively exempt the practice of the reuse of these devices from any risk and reverse, if applicable, the registration of these devices to limited reuse rather than single-use.

\section{Conclusion}

This study confirmed the initial research hypothesis: there was the achievement of sterilization in single-use devices used in video-surgical-laparoscopy (grasper, dissector, scissors, Veress needle and electrosurgical probe system) as well as the equivalent reusable devices, faced with the contamination-challenge with sporulated micro-organisms.

\section{References}

1. Cohoon BD. Reprocessing of single: use devices. Aorn J. $2002 ; 75(3): 557-67$.

2. Agência Nacional de Vigilância Sanitária (ANVISA) (BR). Resolução RE no. 2605, de 11 de agosto de 2006. Estabelece a lista de produtos médicos enquadrados como de uso único proibidos de ser reprocessados. Diário Oficial da União [periódico na Internet] 14 ago.2006 [acesso 20 novembro 2006]. Disponível em: http://e-legis.anvisa.gov.br/leisref/public/showAct. php?id=23407\&word

3. Roth K, Heeg P, Reichl R. Specific hygiene issues relating to reprocessing and reuse of single-use devices for laparoscopic surgery. Surg Endosc. 2002; 16(7):1091-7.

4. Graziano KU, Balsamo AC, Lopes CLBC, Zotelli MFM, Couto AT, Paschoal MLH. Critérios para avaliação das dificuldades na limpeza de artigos de uso único. Rev. Latino-Am. Enfermagem. 2006;14(1):70-6.

5. Pinto TJA, Graziano KU. Reprocessamento de artigos médicos-hospitalares de uso único. In: Fernandes AT, Fernandes MOV, Ribeiro N Filho. Infecção hospitalar e suas interfaces na área de saúde. São Paulo: Atheneu; 2000. p. 1070-8.

6. Goveia VR, Pinheiro SMC, Graziano KU. Lowtemperature sterilization and new technologies. Rev. Latino-Am. Enfermagem. 2007;15(3):373-6.

7. Rutala WA, Weber DJ. Guideline for disinfection and sterilization in healthcare facilities [internet]. Atlanta; 2008. 158 p. Disponível em http://www.cdc.gov/incidod/ hip/dsguide.htm

8. Alfa MJ, Nemes R. Inadequacy of manual cleaning for reprocessing single-use,triple lumen sphinctertomes: simulated-use testing comparing manual with 
automated cleaning methods. Am J Infect Control. 2003;31(4):193-207.

9. Ribeiro SMCP. Reprocessamento de cateteres de angiografia cardiovascular após uso clínico e contaminados artificialmente: avaliação da eficácia da limpeza e da esterilização [tese]. São Paulo: Escola de Enfermagem da Universidade de São Paulo;2006.

10. Santos VS, Zilberstein B, Possari JF, Santos MA ; Quintanilha $A G$, et al. Is it possible to reprocess it after the first use? Surg Percutan Endosc Laparosc Tech. 2008;18(5):464-8.

11. Batista Neto S, Graziano KU, Padoveze MC, Kawagoe JY. The sterilization efficacy of reprocessed single use diathermy pencils. Rev. Latino-Am. Enfermagem. 2010;18(1):81-6.

12. Pinto FMG. Análise da carga microbiana de instrumentos identificada após o uso em cirurgias ortopédicas [dissertação de Mestrado]. São Paulo: Escola de Enfermagem da Universidade de São Paulo;2009.

13. Balsamo AC. Avaliação da eficácia da limpeza e desinfecção de alto nível na remoção do biofilme em canais de endoscópios [Tese de Doutorado]. São Paulo: Escola de Enfermagem da Universidade de São Paulo;2009.

14. Psaltikidis EM, Graziano KU, Frezatti F. Análise dos custos do reprocessamento de pinças de uso único utilizadas em cirurgia vídeo-assistida. Rev. Latino-Am. Enfermagem. 2006;14(4):593-600.

15. Gartner D, Munz K, Huckelheim E, Hesse U. Ultrassonic scissors. New vs resterilized instruments. Chirurg. 2008;79(2):175-9. 